\title{
New Periodicals of I95 I-Part I
}

Miss Brown is head, Serials Section, Descriptive Cataloging Division, Library of Congress.

$\mathrm{V}$ ARIETY of subject matter is the predominant characteristic of the new periodicals examined during the first half of 195I. Few journals were received from Europe and very few of importance seem to have been launched in the United States. It is hoped, however, that from the following short list attention may be called to some titles which might otherwise have been overlooked.

\section{Book Reviews and Bibliography}

Psychological Book Previews is made up of authors' descriptive summaries of their own new books on subjects of interest to psychologists. As the title implies, these previews are published before the books appear. The author, assumed to be the person most able to write accurately and without bias about what is in his own book, is required to prepare a review free of superlatives and exhortations of excellence. Each summary must contain a statement of the book's purpose, its background, descriptions of some specific facts, experiments or theories, and a biography of the author. The Pan American Union launched the Revista Interamericana de Bibliografía which will be devoted to timely and accurate information about new publications, authors and libraries of a Latin American or interAmerican character. It will contain articles on bibliographical subjects, book reviews and a bibliography of books, pamphlets and articles. Headings and general editorial notes will appear in Spanish and English, while articles and bibliographical news will be in Spanish, English, Portuguese or French.

\section{Literature}

Another "little magazine" is Diameter, published in Brooklyn. It aims to publish poetry, stories, one-act plays, radio scripts, original music, criticism in every art, and above all, works by unknown writers. From Oxford, England comes Essays in Criticism. This journal will appear quarterly and will contain every kind of criticism, provided it is good. Illustrative of the contents of the first issue are such articles as "Matthew Arnold and the Modern Dilemma," "The Mystery of Poe's Poetry," and "Teaching English in the Universities." Two student publications were received, Helicon from Clark University and Pennsylvania Literary Review from the University of Pennsylvania. Both include contributions from students and faculty. $R_{0}$ man is a new bimonthly literary journal from France, the first issue of which includes critical studies and original works. The Shakespeare Newsletter, edited and published by Louis Marder, Brooklyn College, contains brief, chatty notes on new Shakespearean performances, new books about Shakespeare, activities of Shakespeare clubs, etc. For lack of a better classification in this list, included here is Check which is made up of reprints and condensations from periodicals, newspapers and books.

\section{History}

History Today is a new British journal which aims to analyze historical trends, 
present essays on literature, science and art and the contribution they have made to the international background, accounts of economic development and a series of articles dealing with the origin and growth of British towns and cities. Articles will be written by experts and are intended to be of interest to the general reader.

\section{World Affairs}

The International Institute of Political and Social Sciences concerning Countries of Differing Civilizations (formerly International Colonial Institute), whose purpose is to promote the development of moral and political sciences in countries where peoples of differing civilizations have been brought into contact, is publishing Civilisations as its organ. The review will publish basic articles including documentary studies, consisting of the synthesis and the analysis of documents concerning the events and tendencies relating to the business of the institute, analytical and critical reports on notable books and articles within the sphere of the studies of the institute. Articles are in French with English summary or English with French summary. The Swiss Review of $W$ orld Affairs is a monthly publication of the Neue Zürcher Zeitung with the University of Chicago Press acting as its American sponsor. Each issue will contain eight to ten articles written in or translated into English by Swiss editors of Neue Zürcher Zeitung and by foreign correspondents. Articles will deal with various areas and issues of current world affairs in an effort to serve the cause of better mutual understanding among the citizens and peoples of the free world. A periodical specializing in articles of an ideological and political nature is Terre Humaine published in Paris. The editors want to present world problems in a manner which will bring hope and encouragement to those persons who feel the political situation is out of control. World Liberalism is a new journal published by Liberal International in London. It will promote the spirit and support the aims of this organization, namely the growth of a free society based on personal liberty, personal responsibility and social justice.

\section{Special Places}

Three new periodicals aiming to interpret each of three places are listed together here, although their purposes have nothing in common. The purpose of Korea is to present to Americans what the Koreans themselves have to say about their present ordeal by fire. The first issue was carried by airplane from Korea during the last week in April I95 I by the Republic of Korea Good-Will Mission to the United Nations. Included are articles entitled "A History of Democratic Movement in Korea," "Whither Our Refugees?" and "The Present Economic Condition of Korea \& Future Prospects" all written by Koreans. Landscape, from Santa Fe, N.M., has for its purpose the presentation of the human geography of the Southwest. Among the articles in the first issue are "Southwestern Colonial Farms," "Chihuahua; As We Might Have Been" and reviews of new books about the Southwest. Sicilia America Illustraxione is being published in Palermo to present Sicily to the stranger. The first number includes interesting articles on Sicilian architecture, history and customs as well as brief abstracts of articles on Sicily from Italian journals and newspapers.

\section{Education}

The Association of Geology Teachers began the publication of Journal of Geological Education to promote high standards of instruction in this field. To note a few of the contributions in the first issue there may be mentioned "An Outline of a Course 
in Elementary Mineralogy," by a member of the Harvard faculty, "Automatic Testing Program in Mineralogy," as conducted at Antioch College, and "Crystallography in the General Mineralogy Course," by an Indiana University professor.

\section{Finance}

Securities in Motion; Monthly Digest of the Relative Performance of Stocks and Stock Groups should be a valuable aid in the making of sound investment decisions. The movement of stocks and their established price trend based on past quotations are reported graphically. The publisher's warning that the charts will not give information on what the future price movements will be must be noted.

\section{Science}

The first issue of The AIBS Bulletin indicates that this publication will be given over to such matters as notes of meetings, new publications, book reviews and other matters of interest to the members of the American Institute of Biological Sciences. The Journal of Applied Chemistry, which supersedes the Journal of the Society of Chemical Industry, contains papers reporting on original investigations. The Annals of the Ukrainian Academy of Arts and Sciences in the U.S. aims to coordinate the efforts of Ukrainian scholars of all varieties of democratic thought and conviction. Illustrative of the content of the first issue are "Historiography of Ukrainian Literature," "A New Soil Map of the Ukraine" and book reviews.

\section{Medicine}

Antibiotics and Chemotherapy will publish experimental and clinical studies on antibiotics and chemotherapeutics, that is, penicillin, streptomycin, aureomycin, to mention a few of the better known ones, and hormones. The contributions to the International Journal of Group Psychotherapy are written by doctors and social workers who are trying out group therapy clinically. It is the official journal of the American Group Psychotherapy Association. Neurology is the official journal of the American Academy of Neurology. This organization feels that since so many illnesses implicate the nervous system, either primarily or in some associated manner, physicians need to be informed of the progress made in this phase of therapy.

\section{Engineering}

The Family Handyman is a new quarterly planned to simplify the making of home repairs and improvements. The editor is Paul de Fur who says he has been a "handyman" since childhood days. He schemes up new and better ways for people to maintain and improve their houses without help from experts. The first issue includes articles on "Fireplace and Flue Faults," "Winterizing Waterpipe," "Snow Removal" and solutions for many other annoying household problems. The Foreman's Digest is made up of condensed articles on industrial management from various engineering and business periodicals. Devoted to all aspects of and uses for audio reproduction is High-Fidelity, the Magazine for Audio-Philes. In fairly simple language the first issue gives advice on such matters as "Selecting a Speaker," and "Housing the Speaker." Also it is intended to include the section "Records in Review" in each issue. From the Hoepli firm in Milan comes Rivista di Ingegneria which supersedes L'Ingegnere. In addition to articles on a wide range of engineering subjects there are included reviews of English, French, German and Italian books, a classified listing of other new books with trade items and notices of meetings and fairs. 
Law

The Buffalo Law Review, published by the University of Buffalo School of Law, is designed to provide the students with an opportunity for legal writing and also to provide a service to the legal world.

\section{Ships}

Ships \& Sailing is an interesting new monthly about ships and the sea. A section of the first issue called "News and Comment" is made up of brief paragraphs on such topics as our lack of fast merchant ships, our new submarines, recent marine expeditions, Japanese shipping, etc. There follows informative and readable accounts on such varied subjects as a Portuguese fishing village, a European cruise on a U.S. Lines freighter, shipping on the Great Lakes and other articles.

\section{Gardening}

From the New York Botanical Garden comes The Garden Journal, which, it would seem, should be of interest to ama- teur gardeners as well as to persons having some training in botany. The first issue includes material on such subjects as window gardening, the botany of Kalalau Valley, Kauau, Hawaii, the Butchart gardens at Victoria, British Columbia, and the care and maintenance of shrubs and vines.

\section{Entertainment}

For lack of a better classification, Lo Spettacolo, Rassegna Economica e Sociale Degli Spettacoli e Delle Attività Artistiche $e$ Culturali is entered here. The introduction prepared by the editor, Antonio Ciampi, states that "the object of this review is to encourage and promote studies concerning the economic and social phenomena resulting from the different forms of entertainment which make use of works of an artistic and cultural nature." The first issue includes such articles as "Remarks Concerning the Economy of the Film Exhibition," "Principal Technical Aspects of Broadcasting," and "Technical and Economic Postulates for Finding New Markets for the I $6 \mathrm{~mm}$ Film."

\section{Periodicals}

The AIBS Bulletin. American Institute of Biological Sciences, 210I Constitution Ave., Washington. v. I, no. I, January I 951 . 5 no. a year. $\$ 2.00$.

Antibiotics and Chemotherapy. Washington Institute of Medicine, 667 Madison Ave., New York 2I. v. I no. I, April i95 I. Monthly. \$10.0o.

Buffalo Law Review. 77 West Fagle St., Room 220 , Buffalo 2. v.r, no.r, Spring I95r. Semiannual. $\$$ I.00 per issue.

Check; Selected Readings From All Sources. Eastern Publishing Company, Concord, N.H. v. I, no. I, March I 95. Bimonthly. \$I.50.

Civilisations. INCIDI, i I Boulevard de Waterloo, Bruxelles. v.I, no.I, January I95I. Quarterly. $\$ 5.00$.

Diameter. I6 I Remsen St., Brooklyn 2: no. I, March I95I. Monthly. \$4.00.

Essays in Criticism. B. Blackwell, 49 Broad St., Ox. ford, England. v.r, no.r, January I95I. 4 no. a year. \$2.10.

The Family Handyman. Universal Publishing and Distributing Corp., McCall St., Dayton, Ohio. v.I, no.I, Winter I95I. Quarterly. \$1.00

The Foreman's Digest. I 8 South Dean St., Englewood, N.J. v. I, no. I, May r 95 I. Monthly. \$6.0o.

The Garden Journal. New York Botanical Garden, Bronx Park, New York 58. v.I, mo. I, January/Feb-

Helicon. Clark University, Worcester, Mass. Spring 1951. Frequency not given. Price not given.

High-Fidelity, the Magazine for Audio-Philes. Radio. com, Inc., 264 Main St., Great Barrington, Mass. v. I, no.I, Summer 1951. Quarterly. \$3.00.

History Today. 72 Coleman St., London, E. C. 2. January I95I. Monthly. 30s.

International Journal of Group Psychotherapy. International Universities Press, 227 West 13 St., New national Universities Press, 227 West 13 St., New
York II. v.r, no.r, April I95I. Frequency not given. \$7.50.

Journal of Applied Chemistry. Society of Chemical Industry, 56 Victoria St., London, S.W.r. v.r, pt.r, January I $95 \mathrm{I}$. Monthly. £2.

Journal of Geological Education. W. F. Read, Lawrence College, Appleton, Wis. v. I, no. I, April I95I. 2 no. a year. $\$ 2.00$.

Korea. Korean Pacific Press, I620 Eye St., N.W., Washington. v.I, no.I, April I951. Monthly. \$3.50. Landscape; Human Geography of the Southwest. Box 73, Santa Fe, N.M. v. I, no.I, Spring r95r. 3 no.

Neurology. $\$$ L. M. Cohen, 84 South Ioth St., Minneapurology. L. M. Cohen, 84 South I oth St., Minnea-
polis 3. v.I, no. I, January/February I95I. Bimonthly. $\$ 8.00$.

Pennsylvania Literary Review. University of Pennsylvania, Philadelphia. v. I, no.r, Spring r951. 4 no.

Psychological Book Previews. 3 I Markham Road, Princeton, N.J. v.I, no.I, January I95I. Quarterly. $\$ 4.50$.

Revista Interamericana de Bibliografía. Pan American Union, Washington 6. v.r, no.r, January/March I 95 I. Quarterly. \$3.00.

Rivista di Ingegneria. Via Cerva 22, Milano. v.I, no.I, January I95I. Monthly. \$I0.00. 
Roman. Saint-Paul, France. no. I, January I951. Bimonthly. Fr. I 200.

Securities in Motion. Data Digests, 74 Broad St. New York 4. v. I, no.I, April I95I. Monthly. $\$ 8.50$.

The Shakespeare Newsletter. 749 Franklin D. Roosevelt Drive, New York 9. v.I, no.I, March I95I. Monthly (September-June). \$I.oo.

Ships \& Sailing. Kalmbach Publishing Company, I027 North 7 th St., Milwaukee 3. v.I, no.I, June I95I. North 7th St., Milwaukee 3. v.I, no.I, June I95I. Monthly. \$5.00.

Sicilia America Illustrazione. Via Maqueda $256, \mathrm{~Pa}-$ lermo. v.I, no.I. January I95I. Monthly. Li 0.000 .
Lo Spettacolo. Via Valadier 37, Roma. v.I, no.I, January/March I95I. Frequency not given. \$5.00. Swiss Review of World Affairs. University of Chicago Press, 5750 Ellis Ave., Chicago 37. v. I, no.I, Jan-
Pats uary I95I. Monthly. \$7.00.

Terre Humaine. 43 Rue de Liège, Paris 8. no.I, January I95I. Monthly. Fr. I600.

Ukrainian Academy of Arts and Sciences in the U.S Annals. v. I, no.I, Winter I951. Semiannual. \$1.00 per issue.

World Liberalism. Liberal International, 39 St. James Place, London, S.W. I. v.I, no.I, Spring I95I. Frequency not given. Membership I ss.

By M. ALLYN FOX

\section{Friends of the Library Groups in Colleges and Universities}

Mr. Fox is executive assistant, Brooklyn College Library.

$\mathrm{T}$

HIS ARTICLE summarizes a survey of Friends of the Library Groups in colleges and universities. The survey was part of an investigation which may result in a revised edition of previous ALA publications on Friends Groups. The manuscript is now in the hands of the Committee on Friends of Libraries.

A questionnaire was sent to the 102 groups known to exist in 1949 . Of 69 respondents, 37 had groups actively functioning, while 32 did not.

The reasons given most often are to promote interest and support and to acquire materials beyond the reach of ordinary budgets.

The most popular form of name is Friends of the ... Library. Others are Library Associates, Library Guild, Association of the Friends of . . Library, Association of Patrons and Friends of ... Library and Society for the Libraries.

The outline which follows provides an idea of the variety of officers in 30 groups. Titles were furnished by the respondents.
Personal contacts and direct mail are used equally to secure new members. Personal solicitation, suggestions by present members and word-of-mouth advertising are included in the former category. Direct mail consists of letters, invitations to events and various types of brochures.

The number of members ranges from about 25 to 399. All sorts of occupations are represented. A third of the groups accept students for membership. More than half of the groups do not accept business firms as members, but do accept clubs and societies.

About half of the groups are dissatisfied with their rate of growth, stating that too little time is available for promotional purposes.

The prime mover behind the organization of the groups is the librarian. Faculty, alumni and administrative officers are next in importance as organizers. Of 32 groups reporting on this question, 24 replied that the librarian was an officer of their groups.

The librarian plans and arranges meetings, solicits and acknowledges gifts, solicits members and keeps records..

Slightly more than one half of the groups 